\title{
Entre o mérito e a sorte: escola, presente e futuro na visão de estudantes do ensino fundamental do Rio de Janeiro
}

\author{
Marcio da Costa \\ Universidade Federal do Rio de Janeiro, Programa de Pós-Graduação em Educação

\section{Mariane Campelo Koslinski} \\ Universidade Federal do Rio de Janeiro, Programa de Pós-Graduação em Sociologia e Antropologia
}

\section{Primeiras considerações}

Nossa intenção, ao tomar a iniciativa de realizar a pesquisa financiada pelo Conselho Nacional de Desenvolvimento Científico e Tecnológico (CNPq) que resultou neste artigo, era compreender um processo social que estaria manifestando-se, entre outros aspectos, por um preocupante processo de esvaziamento de significado do espaço escolar, para uma parcela da população. Esse processo se manifestaria por severos problemas de disciplina, ${ }^{1}$ violência e desinteresse, no âmbito da instituição escolar, e seria aparentemente contradito pelo afluxo crescente de candidatos ao alistamento escolar, bem como pela indiscutível relevância que a educação escolar desfruta entre os discursos que alcançam repercussão pública. No entanto, o fenômeno sob nossa atenção ocorreria entre uma parcela so-

${ }^{1}$ Roure (2001) apresenta uma revisão da literatura recente sobre a questão da indisciplina escolar no Brasil, na qual questiona os limites das abordagens de cunho psicológico em tratar suficientemente da questão. cial de baixa capacidade de expressão pública e estaria condicionado por uma combinação de fatores, entre os quais se destacaria a forte redução na mobilidade social em nosso passado recente, por força do estancamento do desenvolvimento econômico. ${ }^{2}$

Desenvolvendo a pesquisa de campo, deparamonos com resultados que tendem a fortalecer nossa hipótese principal. Porém, outras questões foram levantadas, de forma a tornar mais complexa nossa compreensão do fenômeno. Até que ponto os fatores extra-escolares - socioeconômicos e familiares - podem ser responsáveis por menores expectativas escolares e de futuro, menor adesão aos procedimentos e comportamentos "desejáveis" diante do que a escola ${ }^{3}$ espera por parte de um alunado bem diferenciado quanto a esses últimos aspectos?

${ }^{2}$ Uma explicação mais detalhada das bases teóricas da pesquisa pode ser encontrada em Costa (2001).

3 "Escola" é uma generalização que contempla muita diversidade. Porém, toda escola supõe adesão de seus freqüentadores a regras estabelecidas e a seus objetivos formais. 
Os resultados preliminares ${ }^{4}$ de nossa pesquisa parecem indicar que as experiências de escolarização percorridas pelos alunos, suas vivências no âmbito intra-escolar, jogam papel bastante relevante na atitude de maior ou menor valorização conferida à escola e, portanto, no comportamento mais ou menos "construtivo" diante da instituição escolar desenvolvido pelos estudantes. Essa possível constatação remete ao campo das políticas públicas especificamente escolares um peso maior no enfrentamento de graves problemas de desagregação do espaço educacional institucionalizado, retirando um pouco de relevância da dimensão estrutural socioeconômica mais ampla.

Em contrapartida, é necessário considerar que mudanças nos estímulos culturais para um grupo etário que se configura cada vez mais como um segmento importante de mercado, e a adoção de identidades múltiplas por parte dos estudantes, conforme reconhecido cada vez mais nas reflexões sobre juventude, podem também fornecer compreensão para uma certa retração de uma atitude mais reverente diante da escola, a qual pode ter sido característica de momentos anteriores.

$*$

No plano da gestão dos sistemas escolares - e dos próprios conflitos sociais envolvendo juventude a perplexidade diante da crescente deterioração do valor da escola origina diversas reflexões. O problema que poderíamos considerar alarmante, observando a literatura crescente sobre escola e violência ${ }^{5}$ no Brasil ou relatos freqüentes na imprensa, possui, porém, dimensão maior que suas manifestações mais agudas podem apontar. A violência referida à escola pode ser considerada resultante de uma certa deterioração nas relações e erosão das regras que regulam e

${ }^{4}$ Quando da confecção deste artigo, um survey com cerca de 2.600 estudantes estava em andamento. Os resultados aqui apresentados referem-se aos dados colhidos por meio de grupos focais.

${ }^{5}$ Ver Zaluar (1992), Zaluar e Leal (2001), Minayo et al. (1999), Guimarães (1998), Candau et al. (1999). definem o espaço escolar. Autores internacionais também se debruçam sobre o tema, ainda que muitas vezes este apareça mais fortemente enquadrado em abordagens normativas que em tentativas compreensivas.

No entanto, apesar da atração do assunto, nosso foco não está voltado para a violência. Se passamos por essa temática, isso se deve a que boa parte da literatura atual sobre juventude e escola se dedica a tratar dessa dimensão. Nosso objeto é o valor atribuído à educação escolar e aos aspectos a que este pode estar associado. A mais instigante reflexão que encontramos sobre o tema do esvaziamento de significado da escola, voltada ao contexto norte-americano, mas com muitos aspectos universais, está em Postman (1996), que desnuda os “deuses” fracassados na constituição do ideário que sustentaria a escola contemporânea. $\mathrm{O}$ autor enfoca filosoficamente o fracasso da escola em disseminar e se nutrir de valores constitutivos de uma sociabilidade que se contraponha a tendências desagregadoras do mundo contemporâneo. ${ }^{6}$ Trata-se, portanto, de uma visão que concentra sua atenção nos valores constitutivos das ordens e práticas escolares.

Dubet (2001), por seu turno, como expressivo de uma corrente de autores voltados ao estudo da juventude que tanto têm influenciado o pensamento educacional brasileiro, volta-se para aspectos identitários desse segmento etário, procurando compreender como novas conformações mais "abertas" de identidades amálgamas de valores - relativizariam atitudes mais reverentes diante da escola e de outras instituições fundamentais da sociedade moderna. Tal linha analítica volta-se, dessa forma, para alterações em elementos gerais da cultura, associados a mudanças substantivas nos arranjos sociais modernos.

De certa forma, ambas as maneiras de abordar a questão apontam um forte descolamento entre o uni-

${ }^{6}$ Postman não deixa de estar retomando a invocação durkheimiana por uma escola republicana que amplie a densidade moral da sociedade, contrabalançando a força centrífuga da divisão do trabalho, nas sociedades de solidariedade orgânica. 
verso escolar e aspirações, comportamentos, enfim, valores presentes ao menos em parte expressiva de sua clientela.

No Brasil, Sposito (2002) e Dayrell (2002), entre outros, têm-se destacado nas tentativas de compreender as relações entre a juventude e o ambiente escolar, a partir das práticas e valores desse segmento etário.

Cremos estar inseridos nessa discussão, procurando compreender uma dimensão especificamente brasileira do fenômeno. Isso nos remete diretamente a uma tentativa de combinar a problemática própria do pensamento educacional com um elemento crucial do quadro social brasileiro: os elevados e persistentes padrões de desigualdade, ${ }^{8}$ combinados ao esgarçamento de laços de solidariedade, conforme definidos na sociologia clássica. Assim, nossa denominação ao projeto "Educação e exclusão social - o sagrado sob ameaça", fonte deste artigo, exprime uma tentativa de compreender um fenômeno educacional pelo ângulo da desigualdade social que ameaça elementos de uma cultura cívica que podem ser considerados antecedentes lógicos da ordem social, algo como um nível pré-contratual.

Escapa às intenções deste artigo desenvolver mais detidamente uma discussão acerca da relação entre educação e igualdade. Procuramos equacionar a questão, para fins de uso nesta pesquisa, da maneira a seguir.

Ao menos do ponto de vista das idéias, educação é um valor firmemente amarrado a alguma noção de justiça distributiva, dado que, na sua própria origem, há uma forte afinidade entre a formação dos sistemas educacionais modernos, o ideário do direito à educação e a recusa a uma ordem social baseada nos privilégios "de sangue".

${ }^{7}$ Destaque-se o precioso trabalho organizado por Marília Pontes Sposito, denominado Juventude e escolarização, publicado em 2002 pelo INEP/COMPED na Série Estado do Conhecimento.

${ }^{8}$ Ver Henriques (2001).
Podemos considerar que, no seu nascedouro, a escola moderna é indissociável da noção de igualdade, ${ }^{9}$ dos valores presentes nesse contexto iluminista, republicano, enfim, moderno. Sua expansão é mais ainda embalada na idéia de franqueamento de oportunidades, emergente nesse processo histórico. ${ }^{10}$ Nossa hipótese trata de uma possível reversão nessa tendência histórica, em alguns segmentos sociais, condizente com a percepção de uma forte limitação de oportunidades, ${ }^{11}$ em meio à crise - especialmente a partir dos anos de 1980 - dos arranjos sociais progressivamente includentes e expansivos.

A constatação de elementos empíricos que fortalecem essa proposição teórica alerta para uma possível perda do valor da escola, tendência configurada na medida em que foram sendo reduzidas as chances de inserção no mundo da modernidade organizada (Wagner, 1994). Não consideramos que a escola sempre desfrutou de valor destacado, posto que é, como instituição universal, característica especialmente das fases maduras de sociedades que se modernizaram. Há, porém, a possibilidade de que, num contexto que reverte tendências importantes de inclusão, o prestígio da instituição escolar enfrente uma inédita traje-

${ }^{9}$ Mesmo que - conforme bem apontam Bendix (1996) ou De Swann (1988) e a sociologia da gênese dos sistemas escolares, por exemplo, em Archer (1979) - os arranjos que engendraram a formação da escola moderna não sejam apenas compreensíveis pela expansão dos ideais de igualdade, estando também condicionados à formação e à afirmação de novas elites políticas, profissionais, burocráticas e econômicas, imbricadas na consolidação do Estado Nacional e da cidadania.

${ }^{10}$ Ainda que parte da literatura consagrada após os anos de 1970 trate essa expansão como um processo funcional de adequação a demandas de uma nova forma de estruturação da ordem social, limitadora das oportunidades e reafirmadora dos privilégios e heranças.

${ }^{11}$ Corrochano e Nakano (2002) comentam algumas teses e dissertações que apontam elementos de um certo questionamento da escola, por parte de alunos trabalhadores. 
tória regressiva. ${ }^{12} \mathrm{O}$ movimento seria análogo e intimamente associado à expulsão de levas de indivíduos dos mercados de trabalho submetidos a regimes formais e, principalmente, à percepção de caminhos bloqueados.

Enquanto são clássicos os estudos sobre oportunidades escolares, os levantamentos estatísticos sobre fluxos e trajetórias educacionais, as análises econométricas ou normativas acerca das imbricações entre padrões de escolaridade e estratificação, mobilidade social ou desenvolvimento ${ }^{13}$, escassos são os trabalhos que investiguem as formas como tais processos são interpretados pelos atores sociais, constituindo uma das bases de sistemas de adesão ou recusa, sempre parciais, da ordem social.

A hipótese que motiva o estudo proposto trata de um fenômeno bastante complexo, na multiplicidade de suas causas possíveis. Há diversas possibilidades de trajetórias que condicionariam a valorização atribuída à educação escolar. Condicionantes no plano das oportunidades escolares, suas características particulares e experiências vividas são muito importantes no valor atribuído por cada um à escola. Outras influências não-escolares, mas a elas associadas, como as representações sobre a escola presentes nos meios dos quais se toma parte, ou o "estilo de vida", devem ser também relevantes. Por fim, as expectativas depositadas sobre a freqüência à escola, sobre as possibilidades dela decorrentes, compõem um quadro geral no qual condicionantes estruturais (oportunidades economicamente condicionadas) e experiências sin-

${ }^{12}$ Collins (2000) realiza uma instigante discussão sobre as possibilidades de expansão dos sistemas escolares atuais, partindo de uma observação macro-histórica das instituições de tipo escolar desde a antiguidade oriental e ocidental. No entanto, as "escolas" antigas não seriam facilmente caracterizáveis como instituições assemelhadas às nossas redes escolares modernas, as quais desfrutaram de prestígio e abrangência sempre ascendentes, desde que se consolidou a tendência histórica à sua universalização.

${ }^{13}$ Ver Reimers (2000) ou Chabbott e Ramirez (2000). gulares devem estar cotejados. Nosso desafio é desvendar se o retraimento das oportunidades de inclusão social exerce papel relevante sobre as representações do papel da escola, o que se manifestaria principalmente sobre aqueles segmentos em maior desvantagem naquele primeiro aspecto.

Para tratar do assunto, recorremos a uma literatura que, de maneira geral, não o enfoca diretamente, mas aborda aspectos intimamente a ele relacionados. Excetuando o estudo de Berends (1995), a literatura mais adequada para lidar com "valor da educação" foi aquela referente às aspirações e expectativas de futuro, além de trabalhos contemporâneos sobre juventude, muito centrados - no que era voltado ao segmento de maior interesse para nós - no fenômeno da violência associado a esse grupo etário.

\section{Aspirações educacionais e expectativas futuras: um breve histórico da literatura}

Por tratar-se de um tema diretamente vinculado ao centro da pesquisa e dos resultados apresentados a seguir, passamos a uma revisão de reflexões sobre educação e expectativas de futuro.

O debate sobre desigualdade tornou-se o centro do conflito político, principalmente depois da Segunda Guerra Mundial, com a disseminação de valores igualitários e com a demanda popular, no que diz respeito a nosso objeto, por oportunidades educacionais iguais (Karabel \& Halsey, 1977). Inúmeros estudos no campo da sociologia da educação, desde então, têm tratado de temas tais como a capacidade de a educação promover mobilidade e maior igualdade, procurando calcular as chances de crianças de diferentes origens de classe de alcançar vários estágios no processo educacional. Alguns desses estudos, mesmo não tratando de um conceito mais amplo de "valor social da escola", focalizam os efeitos tanto de atributos socioeconômicos como de certas práticas escolares sobre um aspecto que se associa aos interesses deste estudo, qual seja, as aspirações e as escolhas educacionais e de carreira dos alunos. 
Discutiremos a seguir essas diferentes abordagens que têm tratado a questão das aspirações de escolarização e das escolhas de carreiras dos alunos, e alguns estudos recentes na literatura norte-americana que, ao tratarem dessas questões, focalizam o cotidiano escolar.

\section{Aspirações educacionais e o estrutural-funcionalismo}

O foco dos estudos no campo da sociologia da educação na década de 1950 concentrava-se na importância de educar potenciais talentos para desenvolver recursos humanos em meio a um contexto de rápida mudança tecnológica. Esses estudos pretendiam servir de subsídio para reformas educacionais que promovessem maior eficiência das escolas, e vinham como resposta a críticas sobre desigualdade de oportunidade educacional entre classes. Tentava-se calcular as chances de alcançar vários estágios no processo educacional para crianças de diferentes origens de classe.

No inicio da década de 1960, estudos elaborados por Clark (1961) e Turner (1961) mostram certos aspectos das normas de mobilidade e do sistema educacional norte-americano - quais sejam, a competição prolongada e mecanismos para "esfriar" aspirações que serviriam para legitimar o sistema social ou evitar revoltas contra este.

Turner (1961) afirma que as normas ou valores que organizam o modo "aceitável de mobilidade ascendente" nos EUA são caracterizados por uma "mobilidade competitiva" (contest mobility). Essas normas de mobilidade, que prevalecem naquele país, seriam caracterizadas por valorização da competição aberta; isto é, nessa sociedade acredita-se que o status de elite é alcançado pelos esforços dos aspirantes em uma competição caracterizada pelo "fair play".

Os indivíduos são encorajados a verem-se como competidores por uma posição de elite. Para que o sistema de mobilidade se justifique, ou seja aceito, os pontos absolutos de seleção para mobilidade ou para imobilidade são postergados, fator que conseqüentemente contribui para aumentar as aspirações escola- res dos alunos. O autor aponta que o sistema educacional norte-americano prolonga essa competição por meio de diversos mecanismos e procedimentos na universidade que constantemente testam e mantêm os alunos em competição.

Outro estudo, também dentro de uma abordagem estrutural-funcionalista, é apresentado por Clark (1961), que focaliza os mecanismos presentes nas universidades que esfriam (cool-out) as expectativas dos alunos. Para o autor, "um grande problema para a sociedade democrática é a incompatibilidade entre o encorajamento, a performance e as realidades de oportunidades limitadas" (p. 513). Por isso, para que o sistema social seja legitimado, precisa de instituições que sejam capazes de bloquear o acesso para níveis mais altos e que ajustem aspirações às oportunidades, sem causar trauma ou revolta em relação ao sistema social.

Mesmo que o acesso à educação superior seja bastante aberto no contexto norte-americano, o autor sugere a importância dos processos de "aconselhamento" ou "orientação" e de "reorientação" para o redirecionamento de alunos que apresentam menor rendimento. Esses alunos, ante as evidências e a uma auto-avaliação de suas performances, são encorajados a desistir de sua intenção inicial de alcançar um diploma de bacharel em um college de quatro anos, e são encaminhados a programas vocacionais, ou semiprofissionais.

Para os autores, em um sistema educacional aberto e competitivo como o norte-americano, as aspirações precisam ser moldadas por certos mecanismos, que, ao realizarem suas funções, contribuem para o funcionamento e legitimação do sistema social.

\section{Aspirações educacionais e as teorias da reprodução}

A partir da década de 1960, com o acirramento de conflitos diversos e com o avanço de valores igualitaristas, novas abordagens e interpretações ganham força no âmbito da sociologia da educação norte-americana e européia. $\mathrm{O}$ estrutural-funcionalismo 
torna-se centro de debate e de controvérsias no campo da sociologia geral e, por conseqüência, no campo da sociologia da educação.

Diversas abordagens no campo da sociologia da educação passam a considerar a escola como reprodutora de desigualdades. Numa sociedade em que a divisão do trabalho depende não só da propriedade de capital, mas também da educação e de habilidades, as escolas adquirem importante papel na reprodução e legitimação dessa forma moderna de estrutura de classes (Bowles, 1977). A escola é vista como reprodutora, seja porque reproduz um padrão de cultura de classe de uma geração para outra, ao passo que as medidas de capacidade intelectual oferecem uma aparência meritocrática que mascara esse mecanismo (Bowles $\&$ Gintis, 1977), ou porque sua principal função é vista como a de ensinar culturas de status (Collins, 1977). $\mathrm{Se}$, de um lado, os estudos realizados dentro de uma perspectiva do estrutural-funcionalismo viam o sistema educacional como oferecendo e limitando oportunidades para a mobilidade de indivíduos, as abordagens que ganham força a partir desse período enfatizavam o papel da educação em manter um sistema de desigualdade socialmente estruturado.

Ainda que diferentes quanto à "postura crítica" diante da sociedade, tais abordagens podem ser tratadas como em seqüência, já que supõem a funcionalidade dos sistemas escolares diante de um mundo social coerentemente ordenado.

Bourdieu (1977) é talvez o principal expoente dessa nova abordagem, ao explicar os mecanismos que asseguram a reprodução da estrutura de relações de classe. Ao introduzir o conceito de habitus, ou seja, o sistema de disposições que age como uma mediação entre estruturas e práticas, que são incorporados por indivíduos pertencentes a diferentes origens familiares e de classe, sua perspectiva pode permitir maior espaço para uma análise da ação dos indivíduos. O autor propõe

[...] o estudo de leis que determinam a tendência de estruturas de reproduzirem a elas mesmas através da produção de agentes dotados de um sistema de predisposições que é capaz de engendrar práticas adaptadas à estrutura e, portanto, contribuir para a reprodução de estruturas. (p. 487)

Para Bourdieu, a escola tende a reproduzir a estrutura de capital cultural entre as classes e a reforçar as desigualdades sociais iniciais, já que mede ou premia o capital cultural previamente adquirido no âmbito familiar. Assim, a estrutura social cria indivíduos com diferentes predisposições em relação à escola. Uma predisposição negativa, que resulta em autoeliminação de classes culturalmente menos favorecidas, é vista como

[...] uma antecipação que se baseia em uma estimativa inconsciente das probabilidades objetivas de sucesso possuídas por toda uma categoria, das sanções objetivamente reservadas pela escola para aquelas classes, ou seções de uma classe, desprovidas de capital cultural. (1977, p. 495)

Tal perspectiva, ao tratar as expectativas e aspirações em relação à escola como produtos de predisposições internalizadas, que levam os indivíduos a agirem de tal forma que reproduzam a estrutura social existente, difere bastante daquelas que apontam que aspirações são limitadas por mecanismos que promovem competição e premiam o mérito, ainda que suponham um mesmo desfecho final (Turner, 1961; Clark, 1961).

\section{Aspirações escolares e as novas abordagens para o papel da escola}

Outros estudos, baseados em análises do sistema educacional norte-americano, fogem de explicações que privilegiam fatores relacionados à habilidade, recursos sociais e culturais, ou fatores relacionados às classes sociais dos alunos para explicar suas aspirações ocupacionais e educacionais. Estudos na tradição da etnometodologia e do interacionismo simbólico apontam para a capacidade de procedimentos escolares - tais como as percepções dos administradores e dos professores da escola - de moldarem as aspirações dos alunos. 
Cicourel e Kitsuse (1977) enfocam certas contingências da organização administrativa e das decisões do pessoal das escolas secundárias norte-americanas pelas quais os objetivos dos alunos são processados. Mais especificamente, os autores propõem estudar como certas deliberações rotineiras de aconselhamento nessas escolas estão relacionadas a decisões em relação à entrada ou não no ensino superior, à escolha de universidades de maior ou menor prestígio e à escolha de carreiras pelos alunos. Eles defendem o argumento de que o progresso dos alunos na transição para o ensino superior é contingente às interpretações e julgamentos do pessoal da escola, tendo em vista a biografia, a aparência, a conduta, a classe social e o tipo social do aluno, bem como sua habilidade e sua performance escolar. Os autores concluem que o sistema norte-americano se aproxima das regras caracterizadas por Turner (1961) como mobilidade patrocinada (sponsored mobility). ${ }^{14}$

Já o trabalho de Rist (1977) representa uma tentativa de oferecer um enquadramento teórico para pesquisas que tratam dos mecanismos pelos quais os professores atribuem certas expectativas aos alunos, e como essas são operacionalizadas dentro da sala de aula, constituindo uma profecia auto-realizada.

O autor toma emprestada a teoria da rotulação (labeling theory) para compreender, por meio das interações em sala de aula, como o aluno é rotulado e, conseqüentemente, como sua performance e suas aspirações são afetadas. Se o tratamento dos professores é constante ao longo do tempo e os alunos não resistem aos rótulos a eles atribuídos, o comportamento e performance dos alunos vão conformando-se ao que deles foi originalmente esperado.

Através dessas interações cotidianas e contingências de situações específicas, nas quais os rótulos vão sendo aplicados, o indivíduo vai mudando sua

${ }^{14}$ De acordo com o autor, as regras relacionadas à mobilidade patrocinada consistem em um processo de seleção controlada, no qual a elite seleciona indivíduos com os atributos apropriados para obter o status de elite. autodefinição e, conseqüentemente, sua motivação para performance e suas aspirações futuras.

Estudos mais recentes no campo da sociologia da educação norte-americana fazem uso das abordagens anteriormente discutidas para compreender como outras práticas das escolas secundárias norte-americanas têm afetado as aspirações e escolhas profissionais dos alunos de diferentes origens familiares.

Uma prática bastante discutida por essa literatura é o agrupamento por habilidade, que consiste na divisão de alunos de acordo com performances acadêmicas. Se para alguns autores essa prática permite que professores adaptem suas técnicas de instrução às habilidades dos alunos, as críticas ultrapassam os possíveis benefícios. De um lado, autores apontam que, ao serem divididos de acordo com habilidade acadêmica, os alunos são segregados, também, com base em características sociais, econômicas, de raça e de etnia (Gamorran et al., 1995). Essa prática também é criticada por reforçar a diferença entre os grupos de alunos, uma vez que "as capacidades intelectuais dos colegas constituem um importante recurso de sala de aula" 15 (idem, p. 690) e os professores designados aos agrupamentos de baixa performance apresentam menor motivação e, freqüentemente, são os mais inexperientes.

Ao analisar a prática de tracking ${ }^{16}$ nos EUA, Oakes e Guiton (1995) chegam a conclusões similares quanto às conseqüências dessa prática para o aumento de desigualdades. Os autores, através de um estudo em três escolas secundárias, discutem o im-

${ }^{15}$ Estudos recentes, que recorrem à modelagem estatística multinível, tendem a reforçar essa hipótese por meio do chamado efeito-escola.

${ }^{16}$ É importante ressaltar que o tracking a que os autores se referem não consiste em uma escolha de uma trajetória especificamente acadêmica e uma especificamente vocacional, característica de sistemas educacionais duais, mas na escolha de disciplinas específicas, ao longo do ensino secundário, de caráter acadêmico, que são pré-requisitos para entrada no ensino superior, ou de disciplinas mais vocacionais. 
pacto de aspectos da dinâmica escolar em modelar decisões em relação ao tracking. Para tanto, o estudo sugere uma explicação eclética, combinando uma abordagem técnica-estrutural (por exemplo, que aponta para a relação entre tracking e a estrutura diferenciada da força de trabalho) com explicações culturais (que levam em conta normas relacionadas à raça, à classe social e às expectativas educacionais) e com explicações de tipo estratégico (por exemplo, a escolha dos pais e a pressão que exercem na escola).

Os resultados da pesquisa mostram, de um lado, que os discursos dos professores, conselheiros e administradores sobre suas práticas e percepções estão de acordo com a perspectiva do capital humano. Estes relatam que a diferença do direcionamento dos alunos para caminhos mais acadêmicos ou mais vocacionais é resultado de uma estrutura aberta, justa e meritocrática. Entretanto, os autores observaram que as escolas não estavam engajadas em uma seleção neutra, e que os brancos, economicamente mais favorecidos, e os asiáticos, tinham consistentemente melhor acesso aos cursos que levam ao ensino superior (colleges) e a trabalhos de maior status, se comparados com alunos de minorias "latinas" com a mesma performance escolar.

Entretanto, se a literatura norte-americana identifica que os agrupamentos por habilidade ou as práticas de tracking refletem e reforçam as desigualdades de classe, Broaded (1997) sugere que esses efeitos podem variar de acordo com os contextos da sociedade mais ampla e da natureza da institucionalização educacional.

O autor realiza uma investigação em Taiwan, cujo contexto difere bastante do norte-americano. Se, de um lado, nos Estados Unidos pode-se observar que a "combinação de segregação residencial baseada em raça, etnia e classe social, com o predomínio do financiamento e controle local e do estado da escolaridade, gera os tipos de 'desigualdades selvagens' e faz do tracking uma questão altamente marcada política e moralmente" (Broaded, 1997, p. 38), o contexto de Taiwan é drasticamente diferente. Taiwan apresenta, no que diz respeito ao contexto social mais amplo, menos desigualdades econômicas e menos tensões entre grupos étnicos; e, no que diz respeito à institucionalização da educação, possui um currículo nacional comum e maior padronização entre as escolas em relação ao financiamento e à qualificação dos professores.

O ensino secundário de Taiwan é caracterizado por um forte tracking em seu segundo ciclo, ${ }^{17} \mathrm{e}$ as escolas sentem-se pressionadas a conseguir o máximo de admissão de seus alunos para as escolas secundárias acadêmicas de mais prestígio. Para atingir tal objetivo, no segundo ano do primeiro ciclo do ensino secundário, as escolas organizam as classes em agrupamentos de habilidade, divididos em classes mais e menos avançadas.

Apesar de o currículo nacional ser o mesmo, os alunos das turmas de mais alta habilidade são mais exigidos; deles é esperado um maior preparo para os exames de admissão para a educação pós-compulsória.

$\mathrm{O}$ autor conclui que um dos efeitos do tracking praticado em Taiwan é encorajar o desenvolvimento de forte aspiração acadêmica entre alunos que são postos em grupos/classes de alta habilidade, e coolingout ou diminuir as aspirações daqueles que são designados às classes de menor habilidade. Entretanto, esse resultado não implica aumento de desigualdades sociais. $\mathrm{O}$ autor observa que as variáveis relacionadas à performance escolar, à pontuação e ao nível de habilidade do grupo, têm uma influência mais forte e direta na formação de aspirações educacionais dos alunos do que as variáveis relacionadas à origem familiar consideradas no estudo.

Em suma, em Taiwan, o agrupamento por habilidade e o tracking diminuem a influência da origem social, dada a menor desigualdade social e a padronização do ensino - o que, para o autor, sugere um caráter mais meritocrático do sistema educacional de Taiwan, se comparado com o norte-americano.

${ }^{17}$ Alunos podem prestar exames que os levam para escolas secundárias acadêmicas, para os programas técnicos especializados de cinco anos, e para o secundário vocacional, sendo o primeiro o de maior prestígio. 
Outro estudo que focaliza os efeitos das práticas de tracking é apresentado por Berends (1995). Entretanto, o autor critica estudos que, ao tratarem das atitudes e comportamentos dos alunos, abordam somente algumas das dimensões do que ele chama de social bonding to school, ou laços sociais com a escola.

Para desenvolver seu conceito central, Berends (1995) inspira-se na social bonding theory de Hirschi, usando as dimensões de vínculo, comprometimento, envolvimento e crença. Assim, em sua análise, o autor toma expectativas educacionais, padrões de assiduidade, problemas de disciplina na escola e engajamento com a escolaridade como constructos para medir os laços dos alunos em relação à escola.

Os resultados desse estudo apontam que os impactos sobre algumas das dimensões dos laços sociais em relação à escola podem ser atribuídos às práticas de tracking, mesmo que alguns desses efeitos sejam de tamanho moderado.

Vale ressaltar que, para Berends (1995), expectativas educacionais futuras representam apenas uma das dimensões de um conceito mais amplo, social bonding to school, e este é o que mais se aproxima das questões que pretendemos focalizar neste estudo, na medida em que o autor procura escrutinar diversas dimensões que estão relacionadas a uma variação na adesão à instituição escolar.

\section{Análise dos grupos focais}

Visto que, de acordo com diversos estudos, fatores relacionados à origem social e familiar têm grande associação com as aspirações escolares e ao gradiente de rendimento escolar dos alunos, propusemos investigar algumas percepções de alunos de escolas de ensino fundamental no município do Rio de Janeiro e observar em que medida a diferenciação por trajetória escolar, materializada no pertencimento a diversos status escolares, está relacionada a percepções acerca da educação.

Antes apontamos algumas peculiaridades do contexto institucional do sistema educacional brasileiro em relação às práticas de tracking e ability grouping. Em primeiro lugar, o contexto brasileiro não compreende, formalmente, um ensino secundário dual que se aproxime de Taiwan, no qual alunos são em um momento selecionados para escolas de ensino acadêmico, que permitem acesso ao ensino superior, e escolas secundárias com ensino vocacional, que não permitem tal acesso. Outro importante aspecto é que, apesar de o sistema educacional brasileiro também contar com uma estrutura curricular com base nacional, as escolas brasileiras não apresentam a mesma padronização que as de Taiwan, aproximando-se mais do modelo norte-americano de desigualdade entre instituições. Há uma grande diferença entre as regiões do país, no que diz respeito a recursos aplicados em educação e qualificação de professores das escolas públicas, assim como entre as escolas privadas e as públicas; e, mesmo entre as escolas públicas de uma mesma rede, as diferenças de reputação são reconhecidas pelas secretarias municipais.

Na rede municipal do Rio de Janeiro, além das diferentes reputações das escolas, uma prática informal, aparentemente realizada por várias delas, chamou-nos a atenção. Muitas escolas dividem suas turmas de acordo com a idade dos alunos, sob a argumentação de que alunos se desenvolvem melhor com colegas da mesma idade e em conformidade com preceitos pedagógicos em voga. Sabemos que essa prática informal, conseqüentemente, separa os alunos de acordo com suas trajetórias escolares - isto é, se os alunos entraram cedo ou tarde na escola, se já foram reprovados em alguma série, ou se já se evadiram da escola por algum tempo. Entretanto, quando conversamos sobre essa divisão com a diretora de uma das escolas pesquisadas, ela apontou que alguns alunos de bom rendimento, mesmo que sejam mais velhos, são encaminhados para as turmas “ 01 ", ${ }^{18}$ do tur-

${ }^{18}$ Usamos este rótulo para designar genericamente as turmas consideradas melhores nas escolas, por ser esse um costume bastante generalizado. 
no da manhã, o que sugere que a divisão de turmas também leva em conta a performance dos alunos.

A busca de evidências por meio de grupos focais configurou um momento de pesquisa mais exploratório, sucedido por outro de coleta de dados em maior escala, de forma a propiciar recursos analíticos característicos da pesquisa quantitativa. Para estabelecimento das comparações necessárias, diversos foram os contextos sociais e escolares cujos integrantes foram ouvidos. Buscamos diversidade entre alunos "bons" e "maus", escolas com prestígio igualmente distinto, comportando clientelas socioeconomicamente diferenciadas e sob regime administrativo diverso.

Contamos, para a análise aqui realizada, com dados coletados por grupos focais realizados em três escolas públicas de ensino fundamental da rede municipal do Rio de Janeiro e em duas escolas privadas do mesmo município, com estudantes da sétima e oitava séries.

A Escola A é pública, goza de má reputação e fica situada numa região próxima ao centro da cidade, recebendo alunos também de bairros mais afastados. A Escola B é pública, de média reputação, fica numa área valorizada da orla marítima, com alta concentração de classe média alta. A Escola $\mathrm{C}$ é pública, goza de boa reputação, fica na zona oeste, zona bastante afastada do centro da cidade, numa região com alguns traços rurais. As Escolas A e B recebem uma população razoavelmente diversificada - moradores "do asfalto" e de favelas, oriundos de famílias em geral empobrecidas, mas com padrões culturais bem distintos. Já a Escola C, também pública, conta com um alunado um pouco mais homogêneo, pobre, dada a menor diversificação da área em que se localiza. A Escola D, privada, de reputação inferior, e a Escola E, privada, de melhor reputação, ficam num bairro próximo ao centro, mas caracteristicamente habitado por uma classe média baixa, um bairro marcado pela decadência econômica.

Foram realizados, no total, 15 grupos focais, e cada grupo contou com 10 participantes, sendo meta- de meninos e metade meninas. ${ }^{19}$ Nas escolas públicas, dividimos os grupos focais em alunos pertencentes a turmas 01 (compostas por alunos cujas trajetórias escolares são fluidas e nas quais a relação idade-série se aproxima da relação esperada) e em alunos das turmas 02, 03 ou regular noturno (cujas trajetórias são mais acidentadas e nas quais há maior incidência de distorção idade-série). ${ }^{20}$

Por meio desses grupos focais, de um lado, observamos a avaliação que os alunos fazem de suas escolas, na tentativa de captar características de suas diferentes vivências e experiências intra-escolares. De outro, observamos suas aspirações futuras de escolarização e de carreira, bem como a importância que atribuem à educação, para captar o valor dado pelos alunos à educação escolar.

\section{A percepção dos alunos em relação às escolas e às turmas}

Observamos, primeiramente, as percepções dos alunos quanto à escola que freqüentam. Essas percepções variam muito entre alunos pertencentes às diferentes escolas pesquisadas e, em uma mesma escola, entre alunos pertencentes a diferentes turmas.

Os alunos das turmas 01 da Escola A (de má reputação) apresentam uma visão positiva da escola, com algumas ressalvas. Eles relatam que o ensino é de boa qualidade, embora a escola seja bagunçada e alguns professores ignorem os alunos, como podemos observar nas seguintes falas:

\footnotetext{
${ }^{19}$ Mesmo reconhecendo sua possível contribuição analítica,
} os grupos focais não foram divididos de acordo com gênero, pois essa divisão implicaria a duplicação do número de grupos e tornaria a pesquisa inviável em termos logísticos. As diferenças de gênero, entre outras, serão tratadas em trabalho posterior, cuja análise terá como base os dados coletados no survey.

${ }^{20}$ Nas escolas privadas não foram realizados grupos focais levando em conta o prestígio das turmas, uma vez que a divisão de turmas de acordo com a idade dos alunos não é uma prática adota nesses contextos. 
Eu gosto só de um professor desta escola, porque a gente vai conversar com os professores e eles ignoram, sabe? E eu só não gosto disso, mas o resto é tudo ótimo.

Ela é boa, mas é muito bagunçada.

Esta escola já foi boa. Agora, assim, ficou muita bagunça.

Esses alunos também reconhecem que a escola tem uma má reputação nas redondezas, mesmo que alguns não concordem com ela:

Tem um menino, ele estuda aqui, ele fala assim: "Esta escola é um puteiro".

Eu também acho que ela [a escola] é boa, inclusive o pessoal que olha de fora pensa que só tem marginal, só tem bandido, mas quem tá aqui dentro realmente vê que não é assim.

Eu não me sinto mal estudando aqui; só porque a escola tem a fama que ela tem eu não me sinto mal, eu acho que ela tem ótimos professores, ótimo ensinamento, eu não me sinto mal.

Já os alunos da turma do regular noturno dessa mesma escola (Escola A) apresentam uma visão unanimemente negativa em relação a ela, além de também reconhecerem sua má reputação externa. Entre os pontos negativos mais mencionados estão a bagunça e a falta de segurança:

Eu não acho nada de bom nesta escola. Aqui tudo é uma bagunça...

Eu também não acho nada de bom nesta escola. Aqui não tem aula, não tem controle, não tem segurança. O que tem de bom aqui?! Nada!

As pessoas olham isso como um "puteiro". As pessoas falam isso pra mim: A tua escola é um "puteiro".

E ainda falam da falta de professores e do desinteresse destes e da direção:

Eu não gosto, também, de quando os professores não dão aula. A gente vem para a escola para estudar, mas não tem professor, então pra que vir para a escola?!
Eu não gosto dos professores que dão aula de qualquer maneira, da direção que não faz nada na escola...

Na Escola B esse padrão repete-se. Os alunos das turmas 01, do turno da manhã, acham que a escola é bagunçada. Eles reclamam da depredação e da pichação, e parecem ter vergonha do aspecto físico que ela tem. Além disso, reclamam dos alunos "bagunceiros", que não "querem nada". Entretanto, elogiam bastante os professores, por sua dedicação e amizade.

As turmas 02 (do turno da tarde) dessa mesma escola apresentam uma visão mais negativa. Os alunos também reclamaram da desorganização, da falta de disciplina, da sujeira e da aparência da escola:

Eu não gosto de nada aqui [...] porque a escola já foi boa na época que tinham outros diretores, [...] o colégio virou bagunça, entra quem quiser, sai quem quiser.

[...] só o que você vê aqui é garoto pichando.

O colégio é muito bagunçado.

Mas a percepção desses alunos quanto aos professores e à direção da escola não é tão positiva quanto a dos alunos das turmas 01 :

[...] não sei se é impressão, mas antigamente os professores eram mais atenciosos... acho que eles vêem que alguns alunos não querem nada, e aí eles descontam na gente, por causa de alguns, todos pagam, não ensinam com paciência.

Eles mencionam gostar de alguns professores, aqueles que se preocupam com o aprendizado dos alunos. Entretanto, reclamam que muitos não "explicam bem" a matéria.

Essa diferença de avaliação entre as turmas $01 \mathrm{e}$ turmas 02 e 03 parece não ocorrer na Escola $C$, de boa reputação. De acordo com a percepção dos alunos das turmas 01, a escola é ótima, alguns apontam que é a melhor da região, e ainda que a escola está melhorando em razão das obras em suas instalações. Tal opinião pode ser sintetizada pelas seguintes falas: 
Eu acho que desde o tempo que eu estudo aqui, desde a quinta série, ela está melhorando aos pouquinhos, pelo que eu vejo e ouço em matéria de ensino ela tá boa.

Esta escola é a melhor da região, que eu acho assim.

Eu tive mais ou menos umas três opções de escola para estudar, eu escolhi esta aqui porque eu achei melhor.

A avaliação dessa mesma escola, feita por alunos das turmas 02 e 03, também é positiva:

Eu entrei este ano... achei uma boa escola.

A escola é boa, mas eu continuo aqui porque só vou mudar para outra escola quando estiver no $2^{\circ}$ grau.

Nas escolas A e B pudemos observar uma variação entre as opiniões dos alunos das turmas 01 e das demais turmas, principalmente no que concerne ao ensino oferecido por suas escolas e o empenho dos professores. É interessante notar que somente nos grupos focais realizados nessas escolas os alunos mencionam o tratamento diferenciado/privilegiado dedicado às turmas 01 (turno da manhã).

$\mathrm{Na}$ Escola B, uma fala evidencia a diferença com que a escola trata turmas de diferentes turnos: "E também, se você entra aqui de manhã, é uma coisa, e de tarde é outra, parece que de manhã exigem uma ordem total, então têm que tratar todo mundo igual".

Outro aluno, ao referir-se ao turno da manhã, o caracteriza como tendo "ensino mais forte".

Já na Escola A, são os alunos da turma 01, do turno da manhã, que reconhecem receber tratamento diferenciado. Um aluno desse turno afirma: "Eu acho que o ensino da manhã é melhor do que o da tarde".

Essa percepção de ensino mais forte no turno da manhã, assim como o menor empenho e assiduidade dos professores, também é mencionada por alunos do curso regular noturno da mesma escola. De acordo com a fala de um aluno:

Às vezes a gente não tem aula direito, porque faltam professores. Só temos professores de História e de Matemática quase o ano todo, e Português entrou agora no meio do ano. Os professores que dão aula, até que dão bem, só que eles estão um pouco atrasados em relação a turnos de manhã e de tarde.

Esses resultados remetem-nos ao estudo realizado por Gamorran et al. (1995), que sugere que um efeito colateral da separação de turmas de acordo com as habilidades dos alunos exerce um impacto na motivação e empenho dos professores - o que, conseqüentemente, aumenta a diferença de performance entre as turmas. Na percepção dos alunos das escolas A e B, a direção dessas escolas preocupa-se mais com o ensino e a disciplina das turmas do turno da manhã, e alguns professores se mostram menos comprometidos ou motivados em relação às demais turmas.

Nas escolas privadas observamos tendências distintas, se comparadas com as escolas públicas. Os alunos da Escola D, privada e de má reputação, divergem quanto à qualidade da escola. Alguns alunos apresentam uma percepção positiva em relação ao ensino, aos professores e à coordenação da escola. Mas, quando comparam o ensino com outras escolas privadas, essa qualidade é posta em dúvida, como podemos observar neste depoimento: "O ensino aqui não é tão severo como no meu antigo colégio".

Alguns alunos também relatam que alguns professores são bons e outros são ruins. É interessante observar que, de acordo com esses alunos, os professores são bons porque são divertidos e amigos, e alguns são "chatos" porque "cobram demais". Uma aluna aponta que os alunos da escola são bagunceiros e que as salas de aula são pequenas e mal conservadas.

Os alunos da Escola E, privada e de boa reputação, apresentam uma visão mais crítica de sua escola. Dizem que, em sua maioria, os professores são bons, mas neste caso os considerados bons são os que explicam bem e são rigorosos. Os alunos elogiam as regras rígidas da escola, que evitam bagunça. Entretanto, relatam que as salas são quentes e as cadeiras desconfortáveis, e criticam o currículo e o ensino. Apontam que o currículo poderia oferecer outras disciplinas, como informática e outras línguas estrangeiras, e alguns manifestam o desejo de estudar em outras escolas que ofe- 
reçam mais "qualidade de ensino, mais conteúdo, mais fortes nas matérias".

A crítica mais incisiva dos alunos que freqüentam a Escola E, se comparados com os da Escola D, de má reputação, pode estar relacionada às carreiras de alto prestígio escolhidas por esses alunos e à percepção da longa escolarização como única via para mobilidade social, como veremos a seguir.

\section{Expectativas de escolarização e de carreira}

As expectativas futuras de escolarização e carreira também variam bastante entre as escolas pesquisadas e entre as turmas de uma mesma escola.

$\mathrm{Na}$ Escola A, observamos que alunos das turmas 01, além de sustentarem uma visão mais positiva de sua escola, também apresentam maiores aspirações escolares do que os alunos do regular noturno.

Os alunos das turmas 01, ao serem indagados sobre seus planos futuros, na sua maioria informam o desejo de chegar ao ensino superior e de seguir uma carreira definida. Os alunos mencionam carreiras tais como direito, comunicação e informática. Um dos componentes do grupo revela aspirações não só de concluir a graduação, em história, como o desejo de fazer pós-graduação: "Já pretendo fazer história, mestrado, depois pós-doutorado em ciências políticas. Mas aí tem que fazer fora do Brasil porque não tem curso aqui no Brasil".

Entretanto, alguns alunos expressam dúvidas quanto à carreira que pretendem seguir, ou mostram dúvidas em relação à possibilidade de alcançar seus objetivos:

$\mathrm{Eu}$, assim, até hoje não tenho na minha cabeça a minha formação que eu quero para mim, mas gosto muito de Informática.

Eu vou fazer concurso, vou ver se eu passo. De qualquer jeito eu vou, provavelmente eu vou estar estudando num colégio público, e pretendo fazer concurso para a faculdade de Jornalismo.

As perspectivas de escolaridade dos alunos do ensino fundamental noturno são bem mais modestas.
Os alunos, em sua maioria, afirmam desejar completar o ensino médio, e alguns expressam dúvidas quanto à possibilidade de alcançar esse nível de ensino:

Eu venho para a escola por duas razões: uma é porque com estudo muita gente não está arrumando um emprego, imagine sem. Aí, no mínimo, quero terminar o primeiro grau.

Eu venho para a escola pra poder terminar o segundo grau, só. Faculdade e vestibular é bobeira, para mim! Não vou conseguir nada mesmo! Segundo grau, se conseguir!

Eu vou tentar estudar até o segundo grau e parar, e se não conseguir vou parar na mesma. De segundo grau pra lá não vou conseguir nada mesmo.

Eu vou parar também no segundo grau, se chegar lá.

Somente um aluno menciona o trabalho que gostaria de ter, motorista de ônibus, que não está atrelado a uma carreira de ensino superior.

Essas últimas falas chamam-nos a atenção por dois motivos: de um lado, os alunos parecem não atribuir importância ou não aspirar chegar ao ensino superior; de outro, colocam em dúvida se são capazes até mesmo de concluir o segundo grau. Esses dados parecem indicar que os alunos já incorporaram predisposições negativas, ou, de acordo com Bourdieu (1977), já anteciparam uma estimativa inconsciente de suas probabilidades de sucesso. Além disso, os alunos demonstram uma certa desvalorização não só da escola que freqüentam, mas da educação escolar em geral, como algo relevante para suas vidas. Voltaremos a essa questão na sessão seguinte, na qual essa tendência se torna mais evidente.

Vale ainda ressaltar que um dos alunos dessa turma associa diretamente a sua falta de motivação ou aspiração educacional à qualidade de ensino que a escola oferece:

Eu vou fazer um curso de FAETEC. ${ }^{21}$ Só isso! Porque se não fosse isso não vou continuar estudando, porque

\footnotetext{
${ }^{21}$ Fundação de Apoio à Escola Técnica do Estado do Rio de
} Janeiro, instituição estadual que congrega escolas que recebem tratamento privilegiado, comparado às demais da rede. 
estar numa escola como esta, prefiro ficar em casa vendo televisão ou fazer outras coisas.

Já os alunos das turmas 01, mesmo que no futuro não alcancem o ensino superior ou sigam a carreira desejada, não incorporaram idéias de fracasso e mantêm suas aspirações altas.

$\mathrm{Na}$ Escola B, os alunos das turmas 01, turno da manhã, mencionam querer concluir o ensino superior. Algumas das carreiras mencionadas foram ecologia, fisioterapia e medicina. Um aluno disse querer ingressar em uma faculdade, mas ainda não escolheu uma carreira, e outro menciona querer fazer faculdade fora do país. Somente um aluno diz não saber o que fará no futuro.

Já nas turmas 02, turno da tarde dessa mesma escola, alguns alunos mencionam a intenção de fazer faculdade, mas poucos foram capazes de mencionar que carreira gostariam de seguir. Dois alunos apontaram para as seguintes carreiras: direito e arquitetura. Os outros mencionaram carreiras vagas, não necessariamente atreladas ao ensino superior:

Eu e ela queremos ter o nosso grupo e dançar.

Eu quero ser MC.

Antes eu queria ser médica de autópsia, mas eu vi que não era o meu dom, eu queria decorar apartamento, ou criar assim.

Já na Escola C, de boa reputação, alunos tanto das turmas 01 quanto das turmas 02 e 03 apresentam, em sua maioria, aspirações de alcançar o ensino superior.

Nas turmas 01, na sua maioria os alunos não só pretendem fazer curso superior, como dizem já ter escolhido os cursos ou carreiras que pretendem seguir. Alguns dos cursos mencionados foram letras, direito, economia e veterinária. Uma aluna diz querer ser professora e atriz; ainda assim, menciona que para ser atriz precisa fazer "faculdade de quatro anos".

Poucos alunos apontam não saber que carreira vão seguir, ou falam de uma carreira indefinida, mas ainda assim mantêm as aspirações em relação ao en- sino superior: "Quando eu terminar a oitava eu vou terminar um ciclo, aí eu quero fazer o segundo grau e depois uma faculdade, mas eu não sei qual, ainda”.

A carreira militar também é mencionada por alunos dessas turmas.

As turmas 02 e 03 mencionam menos suas aspirações em relação ao ensino superior, se comparadas com as turmas 01, e são menos determinados em relação às carreiras que pretendem seguir. Dois alunos mencionam querer fazer faculdade de direito. Outros, ao serem indagados sobre suas perspectivas futuras, apontam para a vontade de continuar estudando, mas sem ter um curso definido: "Fazendo faculdade e arrumando emprego... estudar para o vestibular".

Uma outra aluna expressa sua vontade de continuar estudando e revela a carreira que gostaria de seguir, apesar de duvidar das possibilidades reais de segui-la:

Eu gostaria de continuar estudando, fazendo vestibular, uma faculdade... Eu gostaria de fazer medicina. Eu sei que não dá para fazer, mas eu sempre gostei...

Os grupos focais realizados nessas três escolas públicas sugerem uma significativa diferença entre as aspirações dos alunos das turmas 01, que em sua maioria pretendem chegar ao ensino superior e já escolheram uma carreira definida, e dos alunos das turmas 02 , 03 e regular noturno. É interessante notar que os alunos dessas turmas pertencentes às escolas A e B, que, como vimos anteriormente, apresentam visões negativas em relação aos estabelecimentos em que estudam, tendem a apresentar menores aspirações de escolaridade e carreiras mais indefinidas, se comparados com os alunos das turmas 02 e 03 da Escola C, de maior reputação, mesmo que essa última escola esteja localizada em uma das regiões mais pobres do município. Esses resultados sugerem que a reputação das escolas e os procedimentos internos por elas adotados estão associados e, de alguma forma, podem estar influenciando as expectativas futuras dos alunos.

Nas escolas privadas, voltamos a observar uma tendência de aspirações de escolarização mais eleva- 
das. Os alunos da Escola D dizem que pretendem seguir carreiras de prestígio como medicina e direito; identificam também carreiras na área de informática e teatro. É interessante notar que alguns alunos também têm aspirações em relação à carreira militar: "ser oficial do exército", "entrar para a marinha". Alguns manifestaram desejo de em dois anos estarem trabalhando, mas disseram que os pais só permitiriam que trabalhassem após o término do ensino médio.

Já na Escola E, a maioria dos alunos informou querer seguir carreiras nas áreas médicas (odontologia, medicina, pediatria...). Outras carreiras mencionadas foram direito, jornalismo, engenharia, biologia, psicologia e pedagogia. Todos os alunos pretendiam completar o ensino superior e já tinham em mente a carreira que gostariam de seguir. Diferentemente dos alunos da Escola $\mathrm{D}$, alguns deles relatam que não pretendem trabalhar tão cedo, porque o trabalho durante os estudos pode comprometer o futuro.

\section{Importância atribuída à escola}

Observamos também as diferentes percepções dos alunos quanto à importância da escola em suas vidas.

Os alunos das turmas do turno da manhã da Escola A, de má reputação, ao serem perguntados por que vão à escola, apontaram para um motivo bastante recorrente: para obter melhores perspectivas futuras. Os alunos, em geral, concordam que a escola é importante para "vencer na vida", "para ter emprego digno" e, conseqüentemente, para que possam ajudar suas famílias. O depoimento abaixo ilustra essa percepção:

Eu quero ter um emprego digno para ajudar minha mãe, tirar minha mãe do morro, porque eu não pretendo morar para sempre no morro. Eu não quero isso pra mim, nem pra minha mãe. Eu quero morar na rua, ter uma casa boa.

A escola também é vista por esses alunos como um local de socialização, onde eles podem encontrar amigos, praticar esportes e ter acesso a lazer seguro. Essa percepção é resumida na seguinte fala:
Eu venho de uma forma geral, também, tem a aula que eu sei que preciso da educação, mas tem meus amigos no pátio, tem esportes também que eu faço, tem conversa, tem namoro.

Os alunos ainda se referem a outras importantes funções da escola para suas vidas: disseminação de informação (sobre sexo, por exemplo), formação de valores e de caráter e prevenção contra o uso de drogas e contra a entrada "na vida do crime".

Eu acho que o ginásio é mais importante ainda, porque é mais voltado para os jovens de 13 a 16, 15 anos, e é a idade que vai formar nosso caráter, no futuro, porque formou agora, no futuro não muda mais.

Sem escola, acho assim, sem escola a gente não é nada. Porque é melhor a gente vir para a escola do que ficar na rua roubando, sabe, sendo bandido no morro, você vira bandido hoje pro outro dia você morrer.

A escola, para esses alunos, parece ser muito mais que um instrumento de ascensão social:

De uma forma geral, escola é quase tudo, é praticamente tudo que tem em nossa vida.

A casa, é nossa segunda casa.

Você aprende muito mais coisas, eu acho, aqui na escola, do que em casa.

Os alunos da turma do regular noturno dessa mesma escola não atribuem uma importância tão diversificada ao papel da escola. Muitos a percebem como meio de conseguir um emprego e de alcançar estabilidade:

Para mim, a escola serve para nos preparar e no futuro arrumar um emprego melhor.

Para mim, também serve para adquirir conhecimento e arrumar um emprego futuramente, para poder ter estabilidade.

Importante ressaltar que esses alunos não usam termos como "melhorar de vida", mas percebem a 
escola como precondição para conseguir ou para manter um emprego. Entretanto, alguns alunos questionam esta relação entre estudo e emprego, e até demonstram um certo desprezo em relação à escola:

A escola serve para estudar e ser alguém na vida, mas muitas vezes ela não é tão importante, porque existem pessoas que não estudaram e hoje estão bem de vida; como exemplos, tem o Romário, Sílvio Santos, entre muitas outras pessoas.

A escola serve para ensinar, mas hoje em dia não sei se ela está podendo fazer isso. Serve para ensinar para as pessoas poderem ter um trabalho melhor, uma situação financeira boa, mas hoje ela não oferece tudo isso. Eu não vejo nada de bom na escola.

Alguns alunos indicam a exigência dos pais como o único motivo para freqüentarem a escola: "Eu venho para a escola porque os meus irmãos ficaram na $6^{\mathrm{a}}$ e $7^{\mathrm{a}}$ série, então a minha mãe me obriga, porque se não fosse, não vinha".

Na Escola B, os alunos da turma 02, do turno da tarde, freqüentemente relatam que freqüentam a escola para que possam continuar seus estudos, seguir uma boa carreira, e para melhora de vida: "Porque eu tenho um objetivo na vida, quero fazer faculdade, trabalhar".

Entretanto, alguns alunos também falam sobre a exigência dos pais como motivo para freqüentarem a escola e revelam que, apesar de reconhecerem a importância da escola, não se interessam pelo estudo:

Eu não sou muito de estudar, teve uma série que eu saía pra ir pra escola e não ia, eu parei, minha mãe não falou nada, falou, me botou de castigo, mas agora que eu moro com meu pai, não, eu sou obrigada a ir pra escola.

[...] tava faltando muito, não tinha gosto de entrar, ficava lá fora, ia pra casa de amiga, mas agora comecei a vir, agora que eu tô sabendo que eu tô com a nota ruim, que se eu subir mais um pouco eu vou passar de ano, então eu tô vindo porque eu quero passar de ano, e qual o prazer que a mãe sente vendo o filho repetir de ano...
Para os alunos das turmas 01 da Escola C, a escola é importante tanto para conseguir um trabalho como para informar e preparar para experiências fora da escola:

[...] se a pessoa não tem um bom estudo ela não consegue sobreviver, tem que estudar bastante pra ter um trabalho decente e poder ter uma família.

Mas na escola você aprende com quem você deve ou não andar, mas se você não estudar não faz as escolhas certas...

Os alunos das turmas 02 e 03 dessa mesma escola destacam que a escola é importante para conseguir um bom trabalho e um "futuro melhor".

A maioria dos alunos da Escola D aponta que a escola tem grande importância para conseguir um bom trabalho e ter um bom futuro. Ao serem indagados por que freqüentam a escola, os alunos em geral responderam:

Para ser alguém na vida.

Porque eu quero ter uma profissão boa quando eu crescer.

Eu venho à escola porque eu acho necessário e essen-

cial, ainda mais para a carreira que eu quero seguir.

Poucos alunos mencionaram freqüentar a escola por obrigação dos pais.

$\mathrm{Na}$ Escola E, motivos similares foram apresentados: "para ser alguém na vida"; "para garantir o futuro"; conseguir "trabalho bom", "carreira profissional", "aumentar conhecimentos".

Alguns alunos também indicam que vêm por obrigação dos pais, mas que freqüentariam a escola mesmo que não fossem obrigados.

Novamente podemos perceber uma associação entre a experiência escolar dos alunos, e/ou a atitude em direção à escola que freqüentam, e a importância que atribuem à escola de forma mais abrangente. Alunos que freqüentam escolas de menor prestígio e turmas "mais velhas" tendem a ver a escola meramente como instrumento para conseguir ou manter um emprego e demonstram certo desinteresse pela educa- 
ção escolar, ou, até mesmo, duvidam de seus efeitos benéficos; enquanto para alunos de turmas "mais novas" as funções são bastante diversificadas e, como nas escolas privadas, sua importância primordial parece ser proporcionar uma possibilidade de "melhorar de vida" ou de alcançar a carreira escolhida. Essa percepção sobre a relação entre escola e trabalho é analisada com mais detalhe a seguir.

\section{Relação escola /trabalho}

Os alunos das turmas 01, turno da manhã, da Escola $\mathrm{A}$, ao serem indagados sobre os fatores que influenciam na hora de conseguir um bom trabalho, apresentaram respostas bastante variadas. Os primeiros fatores mencionados foram oportunidades e "investimentos do país". Só então dois alunos mencionam a importância conjunta de "ter estudo" e de ter oportunidades.

Interessante notar que só um aluno disse que o estudo é o fator fundamental, mas com isso trouxe reações diversas:

Não concordo, porque eu acho que o estudo é um dos fatores.

[...] tem que ter QI (quem indica), tem que ter.

Outros alunos concordaram que ter relações, conhecer as pessoas certas, são fatores importantes.

Alguns alunos mencionam fatores individuais, como "correr atrás", isto é, trabalhar para ter recursos para pagar cursos pré-vestibular, "ter interesse", "traçar objetivos" e "trabalhar duro" (inclusive para ser jogador de futebol). Entretanto, para alguns alunos, as pessoas que possuem mais recursos econômicos estão em posição de vantagem para "correr atrás" e, portanto, possuem mais oportunidades de trabalho. As falas seguintes resumem essa posição:

É, quem estudou em colégio particular a vida inteira, chega na faculdade, vai fazer uma faculdade pública, entendeu? A gente não, a gente que estudou em colégio público a vida inteira vai ter que pagar uma faculdade.
Eles têm mais oportunidade para quem fez faculdade pública.

Junto com a escolarização formal, fazer cursos extracurriculares (informática e línguas) parece ser um importante fator para a maioria dos alunos:

Até para ser gari, tem que ter $2^{\circ}$ grau. Até para ser bandido no morro, tem que ter estudo.

Hoje em dia, em todos os empregos precisa de $2^{\circ}$ grau, você tem que saber inglês, tem de saber mexer em computador...

[...] especialização, por causa que hoje em dia eles não querem qualquer um com uma faculdadezinha qualquer e se eu tiver curso de inglês, informática, espanhol, isso e aquilo, claro, eu vou receber bem mais que uma pessoa comum.

Para um dos alunos esse fator é mais importante do que escolarização formal:

Tem algumas pessoas que nem são formadas, entendeu, mas têm conhecimento em todas essas áreas, que ganham melhor que uma pessoa formada. Tem pessoas formadas varrendo rua.

As opiniões dos alunos da turma do regular noturno da Escola A oscilaram entre o fator estudo e o fator sorte. A primeira opinião manifestada enfatizou o estudo, embora a importância de cursos extracurriculares também tenha sido mencionada: "Primeiramente é o estudo, porque você vai procurar emprego e a primeira coisa que eles perguntam é se você tem estudo".

Em um primeiro momento, alguns alunos concordaram que o estudo é o fator mais importante. Entretanto, outros alunos defendem a importância da combinação dos fatores estudo e sorte:

Eu acho que além do estudo tem que ter muita sorte, porque todo mundo precisa de sorte para conseguir um emprego. Tem muita gente que estudou muito e não conseguiu nenhum emprego. 
Outros alunos relativizam ainda mais a importância do estudo, apontando que este não garante trabalho, e que ter boas relações é um fator mais importante:

Eu acho que o estudo não é tão importante assim, porque tenho um amigo que tudo fez, teve todos os estudos, mas, no entanto, não tem um trabalho e fica mendigando por aí.

Para mim, para melhorar de vida, hoje, não é ter estu-

do, mas sim muita sorte e conhecer pessoas certas.

Os alunos ainda concordaram que ter boa aparência, boa apresentação e "saber falar" são fatores importantes para conseguir um emprego.

Para os alunos da turma 02 da Escola B, essa tendência repete-se: o estudo é visto como um fator muito importante, mas que não garante um futuro melhor. Diversos alunos mencionam conhecer pessoas que completaram o ensino superior e que não conseguiram bons empregos:

A minha irmã está no segundo ano e não quer fazer faculdade, e ela vê pelo exemplo da minha tia, que estudou e não conseguiu trabalho, a única coisa que ela tem é uma escolinha particular que ela mesma construiu.

A minha tia se formou em contabilidade e trabalha como merendeira.

Outros ainda mencionam que, em virtude da concorrência, o estudo não garante um bom trabalho:

[...] eu acho que o estudo inclui ter uma vida melhor, mas não garante nada que eu vá trabalhar com aquilo, e eu conheço, uma mulher que fez faculdade de Pedagogia e não consegue emprego. É a concorrência.

O meu primo tá se formando em relações internacionais, e ele diz pra mim que pra você conseguir subir você tem que se esforçar, porque é muita concorrência, e eu quero me formar em Direito, eu preciso ter todos os livros, os artigos, sem isso eu não sou nada.

Apesar de o estudo não ser um fator determinante, de acordo com esses alunos, ao menos nessa última fala o esforço individual é valorizado.
Para os alunos das turmas 01 da Escola C, o principal fator para conseguir um bom trabalho é o estudo, e esse fator parece estar tornando-se cada vez mais importante:

[...] porque trabalho agora está difícil de arrumar, quem não tem estudo. Às vezes, quando eu era menor, eu falava: vou pra escola pra me preparar pro futuro.

[...] hoje em dia até gari tem que ter estudo, e se a gente não estudar não pode fazer um curso de computação, não pode fazer uma faculdade, então hoje é extremamente necessário...

Outro fator relacionado ao esforço individual também é mencionado: "Trabalhar duro também, ter muita prática também, porque a pessoa, quando quer, consegue, querer é poder".

O fator importância de conhecer as pessoas certas foi mencionado por um dos alunos.

As opiniões dos alunos das turmas 02 e 03 da Escola $\mathrm{C}$ variaram um pouco mais, se comparadas com as dos alunos das turmas 01. O principal fator mencionado foi o estudo: "[...] Acho importante estudar, para depois ter um bom trabalho".

Apesar de uma aluna também mencionar o fator esforço individual, outros alunos associaram a importância de estudar com fatores como sorte e cursos extracurriculares.

Para os alunos da Escola D, o fator predominante é o estudo. Vários alunos concordaram com a seguinte afirmação: "Acho que o mais importante mesmo é o estudo".

Mas outros alunos defendem que estudo é importante, mas ter sorte, conhecer as pessoas certas e ter oportunidades também são fatores que influenciam. Nessa escola, um dos alunos também menciona o caso de pessoas que estudaram e não conseguiram um bom emprego: "Eu já sei de muita gente que estuda muito, se forma como advogado e hoje em dia trabalha como lixeiro. A pessoa tem que ter sorte".

$\mathrm{Na}$ Escola $\mathrm{E}$, o fator estudo foi o único mencionado. Além disso, os alunos acham que, para conseguir um bom emprego, é necessário ter ensino supe- 
rior. Os alunos qualificam ainda mais seus relatos e mencionam que ter estudado em uma boa instituição e ter um bom currículo são fatores essenciais.

De acordo com um dos alunos, bom currículo abrange: "O que você estudou na escola ou na faculdade, como você passou, o tipo de instituição que você estudou".

Para esses alunos, o sucesso profissional está relacionado ao estudo, ao mérito pessoal e à reputação da instituição em que se estuda. Outro fator apontado foi "estar bem informado".

Novamente observamos grandes diferenças nas percepções dos alunos, de acordo com o prestígio de suas escolas e o tipo de turma que freqüentam. Essas diferenças vão desde opiniões mais padronizadas, de que fatores individuais ou relacionados ao estudo (fatores meritocráticos) são os determinantes (Escola E e turmas 01 da Escola C), até opiniões mais divergentes, que relativizam a importância do estudo em detrimento de fatores como sorte e relações sociais (Escola A e turmas 02 da Escola B). Esses dados apresentam-nos indícios de que a opinião sobre a importância da educação escolar para alcançar um bom trabalho ou seguir a carreira desejada parece variar de acordo com a experiência escolar dos alunos, além de variar de acordo com sua expectativa futura de carreira.

\section{Conclusões}

A realização de quinze grupos focais, em três áreas distintas da cidade do Rio de Janeiro, envolvendo estudantes da sétima e oitava séries das redes pública e privada, de escolas de prestígio e localização geográfica diversificados, além de fornecer elementos bastante relevantes para a produção do questionário utilizado no survey que os sucedeu, permitiu observar que há relevantes contrastes nas percepções dos estudantes acerca dos pontos que constituem o cerne da pesquisa. De maneira geral, os grupos focais indicam a existência de expectativas de futuro profissional e escolar bem diferenciadas, conforme as origens socioeconômicas dos estudantes pesquisados, como era bastante previ- sível, em conformidade com a literatura clássica que trata do tema das expectativas desde os anos de 1960. Assim, argumentações que destacam o valor da escola e dos estudos na definição do futuro e, portanto, dão ênfase ao valor da educação em suas vidas presentes, foram encontradas praticamente na unanimidade dos grupos que concentravam estudantes em "melhores" escolas, turmas e situações socioeconômicas favoráveis. À medida que os grupos focais se deslocaram para "áreas periféricas" do núcleo prestigiado da educação (turmas, escolas e população mais pobres), a ênfase na importância da escola para a definição do futuro e no presente vai diminuindo. Esta, no entanto, não é uma trajetória linear ou simples. Nosso estudo apresenta um quadro consideravelmente complexo, em que se cruzam os fortes condicionamentos socioeconômicos com elementos importantes da dimensão cultural, como a localização nas áreas geográficas de uma "cidade partida" e, destacadamente, a própria trajetória escolar dos entrevistados.

Parece-nos que um elemento mais importante que o esperado, na inclinação dos entrevistados em relação ao papel da escola em suas vidas, é sua própria experiência escolar pregressa. Claro que, por características próprias deste recurso de investigação os grupos focais - não nos é possível, a partir dele, inferir qualquer conclusão que controle de maneira confiável as expectativas, visões de futuro, valor da escola, com características familiares, perfis culturais e econômicos dos entrevistados. ${ }^{22}$ Todavia, a impressão emanada desses grupos destaca o peso dos fatores culturais, especialmente a circulação por meios sociais, o aporte familiar e a experiência vivida no processo de escolarização como elementos que complementam, rivalizam ou mesmo se sobrepõem à origem socioeconômica, o que permite ricas indagações acerca da capacidade das políticas públicas em se contrapor a tendências "duras", "estruturais", da sociedade.

${ }^{22}$ O survey realizado em 2003 pretende permitir que análises com esta "precisão" sejam alcançadas. 
Resultados animadores - no sentido da hipótese aqui defendida - foram obtidos por Reis (2004), que encontra significativa diferença no valor dado à educação escolar pelos segmentos polares de nossa estratificação social. Nesse sentido, seus levantamentos empíricos obtiveram resultados claramente dissonantes entre "povo" e segmentos de elites (não somente elite econômica) quanto ao valor que conferem à educação para resolução dos problemas nacionais e numa escala de quais seriam nossos problemas sociais mais destacados.

Como pode-se observar a partir dos relatos selecionados, parece que o valor da educação escolar decresce na ordem prevista em nossa hipótese, mas há elementos perturbadores nessa linha afirmativa. Afinal, no mais pobre e remoto agrupamento ouvido (Escola C), identificamos expectativas de inclusão social e de carreira escolar, bem como apreciações sobre a escola bastante positivas. Entretanto, é forçoso informar que, segundo a diretora da escola em questão, situações como a forte atração do tráfico de drogas e das "galeras" correspondentes (Guimarães, 1998; Minayo, 1999) não chegavam a se constituir um grande problema na área, diferentemente das outras escolas públicas presentes no estudo.

Os estudos referentes à estratificação escolar a partir de critérios de prestígio e trajetória pregressa fornecem referências interessantes para nossas reflexões sobre o valor da escola. Contrariando a uma tendência hipersociológica de estabelecer destinos escolares e sociais como inextricavelmente amarrados por pertencimentos socioeconômicos, parece que a experiência de escolarização fornece elementos relevantes para compreensão dos padrões de "adesão" ao universo escolar e, por conseguinte, aos esquemas mais abrangentes de inserção social.

Os resultados anteriormente apresentados, como tantas vezes já alertado, devem ser considerados integrantes de um estudo exploratório. Porém, há informações bastante interessantes e inquietantes que, de antemão, permitem sugerir as políticas públicas de educação, no Brasil, como um fator de acréscimo na desigualdade social. Afinal, se é correto supor que as tra- jetórias e experiências escolares jogam um papel decisivo na conformação das expectativas de futuro e de inclusão nos benefícios da sociedade nacional, a distribuição, a um amplo setor social, de ofertas escolares tão precárias e inferiores pode ser um fator que se agrega à já temerária desigualdade de oportunidades de inclusão social em outros aspectos, contribuindo para formar elementos de uma cultura cívica disruptiva com relação à ordem social - não no sentido imaginado pelos revolucionários do passado e do presente, mas tendente à anomia e à desagregação.

\section{Referências bibliográficas}

ARCHER, M. S. Social origins of educational systems. London: Sage, 1979.

BENDIX, R. Construção Nacional e Cidadania. São Paulo: EDUSP, 1996.

BERENDS, M. Educational stratification and students' social bonding to school. British Journal of Sociology of Education, v. 16, n. 3, p. 327-352, 1995.

BOURDIEU, P. Cultural reproduction and social reproduction. In: KARABEL, J.; HALSEY, A. H. (Orgs.). Power and ideology in education. New York: Oxford University Press, 1977. p. 487-511. BOWLES, S. Unequal education and the reproduction of the social division of labor. In: KARABEL, J.; HALSEY, A. H. (Orgs.). Power and ideology in education. New York: Oxford University Press, 1977, p. 137-153.

BOWLES, S.; GINTIS, H. I.Q. in the U.S. class structur. In: KARABEL, J.; HALSEY, A. H. (Orgs.). Power and ideology in education. New York: Oxford University Press, 1977. p. 215-232. BROADED, C. M. The limits and possibilities of tracking: some evidence from Taiwan. Sociology of Education, v. 70, p. 36-53, jan. 1997.

CANDAU, V.; LUCINDA, M. C.; NASCIMENTO, M. G. Escola e violência. Rio de Janeiro: DP\&A, 1999.

CHABBOTT, C.; RAMIREZ, F.. Development and education. In: HALLINAN, M., Handbook of the Sociology of Education. New York: Kluwer Academic/Plenum Publishers, 2000. p. 163-187.

CICOUREL, A.; KITSUSE, J. The school as a mechanism of social differentiation. In: KARABEL, J.; HALSEY, A. H. (Orgs.). 
Power and ideology in education. New York: Oxford University Press, 1977. p. 282-292.

CLARK, B. R. The "cooling-out" function in higher education. In: HALSEY, A. H.; FLOUD, J.; ANDERSON, C. A. (Orgs.). Education, economy and society. New York: The Free Press of Glencoe, 1961. p. 513-523.

COLLINS, R. Comparative and historical patterns of education. In: HALLINAN (Org.). Handbook of the sociology of education. New York: Kluwer Academic/Plenum Press, 2000. p. 213-239.

Functional and conflict theories of educational stratification. In: KARABEL, J.; HALSEY, A. H. (Orgs.). Power and ideology in education. New York: Oxford University Press, 1977. p. 118-137.

CORROCHANO, M. C.; NAKANO, M. Jovens, mundo do trabalho e escola. In: SPÓSITO, M. P. (Org.). Juventude e escolarização (1980-1998). Brasília: INEP/COMPED, n. 7, p. 95-134, 2002 (Série Estado do Conhecimento).

COSTA, M. Tempos de desesperança - roteiro para pensar a educação quando o futuro parece sombrio. Humanas, Porto Alegre, v. 24, n. 1/2, p. 186-200, 2001.

DAYRELL, J. Juventude e escola. In: SPOSITO, M. P. (Org.). Juventude e escolarização (1980-1998). Brasília: INEP/COMPED, n. 7, p. 67-94, 2002 (Série Estado do Conhecimento).

DE SWANN, A. In care of the State - health care, education and welfare in Europe and the USA in the modern era. London: Polity Press, 1988.

DUBET, F. As desigualdades multiplicadas. Revista Brasileira de Educação, Campinas: Autores Associados; Rio de Janeiro: ANPEd, n. 17, p. 5-19, maio/ago. 2001.

GAMORRAN, A.; NYSTRAND, M.; BERENDS, M. et al. An organizational analysis of the effects of ability grouping. American Educational Research Journal, v. 32, n. 4, p. 687-715, 1995.

GUIMARÃES, E. Escola, galeras e narcotráfico. Rio de Janeiro: Editora UFRJ, 1998.

HENRIQUES, R. (Org.). Pobreza e desigualdade no Brasil. Rio de Janeiro: IPEA, 2001.

KARABEL, J.; HALSEY, A. H. Education research: a review and an interpretation $I n$ : (Eds.). Power and ideology in education. New York: Oxford University Press, 1977. p. 1-86.
MINAYO, M. C. S.; ASSIS, S. G.; SOUZA, E. R. et al. Fala gale$\mathrm{ra}$-juventude, violência e cidadania na Cidade do Rio de Janeiro. Rio de Janeiro: Garamond, 1999.

OAKES, J.; GUITON, G. Matchmaking: the dynamics of high school tracking decisions. American Educational Research Journal, v. 32, n. 1, p. 3-33, 1995.

POSTMAN, N. The end of education - redefining the value of school. New York: Vintage Books, 1996.

REIMERS, F. Unequal schools unequal chances - the challenges to equal opportunity in the Americas. Cambridge: Harvard University Press, 2000.

REIS, E. P. A desigualdade na visão das elites e do povo brasileiro. In: SCALON, C. (Org.). Imagens da Desigualdade. Belo Horizonte, 2004. p. 37-73.

RIST, R. C. On understanding the processes o schooling: the contributions of labeling theory. In: KARABEL, J.; HALSEY, A. H. (Orgs.). Power and ideology in education. New York: Oxford University Press, 1977. p. 292-306.

ROURE, S. A. G. Concepções de indisciplina escolar e limites do psicologismo na educação. In: REUNIÃO ANUAL DA ANPEd, 24., 2001. Caxambu, Anais... Caxambu, 2001. 1 CD-ROM.

SPOSITO, M. P. Considerações em torno do conhecimento sobre juventude na área de educação. In: SPÓSITO, M. P. (Org.). Juventude e escolarização (1980-1998). Brasília: INEP/ COMPED, 2002. p. 7-34. (Série Estado do Conhecimento, n. 7).

TURNER, R. H. Modes of social ascent through education: sponsored and contest mobility. In: HALSEY, A. H.; FLOUD, J.; ANDERSON, C. A. (Eds.). Education, economy and society. New York: The Free Press of Glencoe, 1961. p. 121-139.

WAGNER, P. Liberty and discipline - a sociology of modernity. London/New York: Routledge, 1994.

ZALUAR, A. (Org.). Violência e educação. São Paulo: Cortez, 1992. ; LEAL, M. C. Violência intra e extra muros. Revista Brasileira de Ciências Sociais, ANPOCS, v. 16, n. 45, p. 5-18, 2001.

MARCIO DA COSTA, doutor em sociologia pelo Instituto Universitário de Pesquisa do Rio de Janeiro (IUPERJ), é professor da Faculdade de Educação e do Programa de Pós-Graduação em Educação da Universidade Federal do Rio de Janeiro (UFRJ). 
Publicou recentemente: Jovens estudantes do Rio de Janeiro: hábitos, valores e expectativas segundo o prestígio de suas escolas (Boletim Soced - Sociologia da Educação, n. 1, 2005, endereço eletrônico: 〈www.maxwell.lambda.ele.puc-rio.br〉); Amor e desprezo: o velho caso entre sociologia e educação no âmbito do GT14 (Revista Brasileira de Educação, n. 22, p. 101-120, jan./abr. 2003); Criar o público não-estatal ou tornar público o estatal? Dilemas da educação em meio à crise do Estado (Revista Brasileira de Educação, n. 18, p. 41-51, set./dez. 2001); Tempos de desesperança: roteiro para pensar a educação quando o futuro parece sombrio (Humanas, Porto Alegre, v. 24, n. 1-2, p. 186-200, 2001); Stimulating citizenship: can educational policy enhance civic culture? (Educational Theory \& Practice, Austrália, Albert Park, v. 22, n. 1, p. 75-93, 2000). E-mail: marcioc@ pobox.com
MARIANE CAMPELO KOSLINSKI, doutoranda do Programa de Pós-Graduação em Sociologia e Antropologia da Universidade Federal do Rio de Janeiro (UFRJ), atualmente participando de estágio no exterior, com bolsa da Coordenação de Aperfeiçoamento de Pessoal de Nível Superior (CAPES), no Institute for Social and Economic Research and Policy (ISERP), da Columbia University. Publicou recentemente: Schooling for success: preventing repetition and dropout in Latin American primary schools (Nova Iorque: M. E. Sharpe, 1999). E-mail: marianeck@yahoo.com

Recebido em abril de 2005 Aprovado em outubro de 2005 
nation. Such children were characterised as possessing mental faculties and moral qualities different from those children from the upper classes. These differences were attibuted to by their social experience and could be corrected by school education. Thus, a school project was defined for this segment of the population based on instruction restricted to reading, writing and arithmetic and above all on moral education, the baseline for turning them into civilised adults.

Key-words: history of childhood; history of education; poor childhood

Escolarizar para moralizar: discursos sobre la educación del niño pobre (1820-1850)

El artículo busca analizar los discursos sobre la educación de la infancia pobre, presentes en la Provincia minera, en la primera mitad del siglo XIX, investigando las cocepciones sobre la educación del niño de las clases sociales inferiores y su papel en la formación de una nación civilizada. Este niño era representado como poseedor de facultades mentales y cualidades morales diferentes de los niños de clases sociales superiores, fruto de su pertinencia social, a ser reparadas por la educación escolar. Así, se definía un proyecto de escolaridad, sólo para ese segmento de la población, fundamentado en la instrucción circunscripta al leer, escribir y contar, principalmente en la educación moral, condición de formación de un adulto civilizado.

Palabras claves: historia de la infancia; historia de la educación; infancia pobre

Marcio da Costa e Mariane Campelo Koslinski

Entre o mérito e a sorte: escola, presente e futuro na visão de estudantes do ensino fundamental do Rio de Janeiro

$\mathrm{O}$ artigo apresenta resultados de uma pesquisa, intitulada "Educação e exclu- são social - o sagrado sob ameaça", que procura identificar fatores que influiriam na formação de apreciações valorativas mais ou menos favoráveis à escola. A hipótese básica da investigação propõe a existência de um esvaziamento do significado do espaço escolar, para alguns setores sociais longamente expostos a um processo de redução das oportunidades de mobilidade social ascendente, pelas vias características das sociedades modernas. Um breve relato da pesquisa com estudantes do Rio de Janeiro é apresentado, bem como sua metodologia - que envolve grupos focais e survey - e uma revisão de literatura aparentada ao problema, a qual antecede a exposição de resultados obtidos por meio dos grupos focais realizados. Os dados sistematizados tendem a fortalecer a hipótese principal: a escola parece um elemento dúbio e questionável para a parcela mais "excluída" dos estudantes ouvidos. Porém, há circunstâncias que confundem este quadro, acentuando a experiência escolar como um aspecto central do valor atribuído pelos estudantes à escola e, de certa forma, contrabalançando os efeitos disruptivos de um quadro econômico de agudos conflitos sociais associados a padrões de desigualdade social extremos e duradouros.

Palavras-chave: sociologia da educação; valor social da educação; juventude e educação; exclusão social; sagrado social

Between merit and luck: school, present and future, in the eyes of high school students from Rio de Janeiro

The paper presents the results of a research, entitled "Education and social exclusion - the sacred under threat", which seeks to identify factors influencing the construction of a more or less favourable value appreciation of school. The main hypothesis of the investigation is that the meaning of the school space is weakening, for some social sectors long exposed to a process of reduction of opportunities for ascendant social mobility through the distinctive channels of modern societies. A brief report of the research focusing on students from Rio de Janeiro is presented, as well as its methodology - which involves focus groups and a survey -, and a literature review related to the issue. The systematised data tend to strengthen the main hypothesis: the school seems to be a dubious and questionable element for the most excluded segment of the students researched. Nevertheless, there are circumstances that confuse this picture, accentuating the school experience as a central aspect of the value attributed by students to school and, in a way, counterbalancing the disruptive effects of an economic framework of deep social conflicts associated with patterns of extreme and long-lasting social inequality.

Key-words: sociology of education; social value of education; youth and education; social exclusion; social sacred

Entre el mérito y la suerte: escuela, presente y futuro en la visión de estudiantes de primera enseñanza de Río de Janeiro

El artículo presenta resultados de una pesquisa denominada "Educación y exclusión social - lo sagrado bajo amenaza", que procura identificar factores que influenciarían en la formación de apreciaciones valorizadas más o menos favorables a la escuela. La hipótesis básica de la investigación propone la existencia de un esvaciamiento del significado del espacio escolar, para algunos sectores sociales largamente expuestos a un proceso de reducción de las oportunidades de movilidad social ascendente, por las trayectorias características de las sociedades modernas. Un breve re- 
lato de la pesquisa con estudiantes de Río de Janeiro es presentado, bien como su metodología - que envuelve grupos focales y observados - y una revisión de literatura aparentada al problema, al cual antecede la exposición de resultados obtenidos por medio de los grupos focales realizados. Los datos sistematizados se inclinan a fortalecer la hipótesis principal: la escuela parece un elemento dubio y cuestionable para la fracción más "excluída” de los estudiantes oídos. Sin embargo, hay circunstancias que confunden este cuadro, destacando la experiencia escolar como un aspecto central del valor atribuído por los estudiantes a la escuela y, de cierta forma, contrabalanceando los efectos disruptivos de un cuadro económico de agudos conflictos sociales, asociados a modelos de desigualdad social extremos y duraderos.

Palabras claves: sociología de la educación; valor social de la educación; juventud y educación; exclusión social, sagrado social

Cynthia Paes de Carvalho

Contextos institucionais e escolarização: uma hipótese de classificação das escolas da rede privada de educação básica

Em interlocução com a literatura da sociologia da educação sobre a transmissão intergeracional do patrimônio cultural nas camadas médias, particularmente no que toca aos investimentos educacionais, foi construída uma tipologia das escolas e das trajetórias escolares da educação básica. A partir de uma hipótese de classificação das escolas da rede privada de ensino no Rio de Janeiro, são descritos os diferentes percursos escolares encontrados e são discutidos alguns resultados da análise dos dados referentes ao grupo estudado. Conclui-se ressaltando o potencial heurístico da caracterização de- senhada, no sentido de ampliar a compreensão do conjunto dos estabelecimentos de ensino básico e enriquecer as possibilidades de análise para além da distinção do caráter público ou privado das escolas.

Palavras-chave: escolas; trajetórias; estratégias

\section{Institutional contexts and} schooling: a hypothesis for the classification of private primary schools

On the basis of a dialogue with the literature of the sociology of education on the inter-generational transmission of cultural patrimony among the middle classes, particularly with respect to educational investment, a typology of schools and primary school trajectories was constructed. Based on a hypothesis for the classification of private schools in Rio de Janeiro, the different school trajectories found are described and some results of the analysis of the data referring to the group studied are discussed. The conclusion highlights the heuristic potential of the characterisation designed in the sense of deepening the understanding of the set of primary school establishments and enriching the possibilities of analysis by going beyond the distinction between the public and private character of the schools.

Key-words: schools; trajectories; strategies

Contextos institucionales y de escolaridad: una hipótesis de clasificación de las escuelas privadas de primera enseñanza En la interlocución con la literatura de la sociología de la educación sobre la transmisión intergeneracional del patrimonio cultural en las capas medias de la sociedad, particularmente lo que concierne a las inversiones en la educación, fue construída una tipología de las escuelas y de las trayectorias escolares de la educación básica. A partir de una hipótesis de clasificación de las escuelas privadas de enseñanza en Río de Janeiro, son descriptos los diferentes trayectos escolares, encontrados y discutidos algunos resultados del análisis de los datos referentes al grupo estudiado. Se concluye resaltando el potencial heurístico de la caracterización delineada, en el sentido de ampliar la comprensión del conjunto de los establecimientos de enseñanza básica y enriquecer las posibilidades de análisis, para lejos de la distinción del carácter público o privado de las escuelas.

Palabras claves: escuelas; trayectorias; estrategias

Alessandra de Morais Shimizu, Ana Paula Cordeiro e Maria Suzana De Stefano Menin

Ética, preconceito e educação: características das publicações em periódicos nacionais de educação, filosofia e psicologia entre 1970 e 2003

Apresenta um estudo bibliográfico referente ao tema "ética e preconceito" no âmbito da educação escolar em periódicos nacionais das áreas de educação, psicologia e filosofia a partir da década de 1970 até o ano de 2003. No total, foram categorizados e analisados 570 textos. Constatamos que, especialmente, nas três últimas décadas, houve uma preocupação, por parte dos pesquisadores, com questões éticas e a problemática da diversidade e suas relações com a educação escolar. Percebemos, também, que algumas revistas científicas se destacaram por apresentar um maior número de produções científicas publicadas com o tema e no período que compreende este estudo. Além disso, a maioria dos trabalhos realizou estudos teóricos e pesquisas bibliográficas em detrimento às pesquisas empíricas. Foi elaborado um índice dos textos pesquisados que, juntamente com o material coletado, funcio- 